\title{
Effect of Physical and Chemical Changes on the Antimicrobial Hctivity of Culture Supernatant Fluid of Lactic Hcid Bacteria
}

\author{
Leila Goudarzi (MSc) \\ Department of Microbiology, Faculty \\ of Science, Alzahra University, \\ Tehran, Iran \\ Rouha Kasra Kermanshahi (PhD) \\ Department of Microbiology, Faculty \\ of Science, Alzahra University, \\ Tehran, Iran
}

Zahra Moosavi-Nejad (PhD) Department of Microbiology, Faculty of Science, Alzahra University, Tehran, Iran

Corresponding Author: Rouha Kasra Kermanshahi

Email: rkasra@yahoo.com

Tel: +989131150779

Address: Department of Biology, Faculty of Basic Sciences, Alzahra University, Vanak square, Tehran, Iran

Received : 06 Sep 2014

Revised: 08 Oct 2014

Accepted: 15 Oct 2014

\begin{abstract}
Background and Objective: Lactic acid bacteria are Gram-positive, catalasenegative, nonsporulating, either rod- or coccus-shaped bacteria that have beneficial effects on their hosts by producing antimicrobial substances such as lactic acid, hydrogen peroxide, bacteriocins and biosurfactants. Bacteriocins are antimicrobial peptides that are produced by bacteria and can inhibit the growth of other bacteria.

Methods: In this experimental study, bacteriocin production by Lactobacilli as known probiotic strains was evaluated in different physicochemical conditions. Antagonistic activity was evaluated using quantitative method of Microscale 0ptical Density Assay (MODA). After neutralization of acid and treatment with various enzymes, temperature, $\mathrm{pH}$ and $\mathrm{NaCl}$ conditions, the antimicrobial activity of culture supernatant fluid of Lactobacillus acidophilus and $L$. plantarum was investigated against pathogenic Proteus.

Results: The culture supernatant fluid of Lactobacilli was sensitive to proteolytic enzymes with relatively good stability to temperature. The antimicrobial activity was also present due to production of bacteriocin under different NaCl conditions (1 to 4\% NaCl) and pH range of 5 to 8.

Conclusion: It seems that the antimicrobial liquid of Lactobacillus strains contains bacteriocin, which shows antimicrobial effects against pathogenic strains of Proteus. To investigate further this effect, some complementary studies should be performed.

Keywords: Bacteriocins, Lactobacillus, Proteus, Physicochemical.
\end{abstract}




\section{INTRODUCTION}

The term 'probiotic' is derived from the Greek language, meaning 'for life'. Lilly and Stillwell first used this term in 1965, as secretory factors of a microorganism that stimulate the growth of another microorganism versus the term antibiotic (1). In 1989, Roy Fuller provided a more comprehensive definition for probiotics; live microbial food supplements that cause useful and beneficial therapeutic and salutary effects in consumers by emplacement in intestine and regulating its microflora (2). Lactic acid bacteria and bifidobacteria are the most common microorganisms used in probiotics. Lactic acid bacteria are natural protectors of urinary tract with a long history in food and fermented products. A number of Lactobacillus, Bifidobacterium and other propionic bacteria strains are known as probiotics for their salutary effects (3). These bacteria are abundant in the nature and human digestive system and produce lactic acid through homolactic and heterolactic fermentation. Lactobacilli are specifically known as beneficial bacteria with the ability to break down proteins, carbohydrates and fats in food and also assist the body absorb essential nutrients such as minerals, amino acids and vitamins required by humans and animals.

These bacteria have strong antagonist activity against a large number of pathogenic and spoilage bacteria by producing organic acids, hydrogen peroxide, diacetyl, inhibitory enzymes and bacteriocins (4).

Bacteriocins are the peptides produced by some bacteria and lactic acid bacteria with antimicrobial activity that prevent the growth of other microbial strains (5). Most of them are deactivated by proteolytic enzymes, because of their peptidic nature. The weak range of activity and their peptidic characteristic distinguish them from antibiotics (6). Klaenhammer (1993) categorized the bacteriocins of lactic acid bacteria into four distinct classes based on their genetic profiles and biochemical properties. Class 1 includes the lantibiotics that are small $(<5 \mathrm{kDa})$, surface-active peptides containing lanthionine, $\beta$-methyllanthionine and dehydrated amino acids. Class 2 includes small $(<10 \mathrm{kDa})$, heatresistant and non-lanthionine surface-active peptides. Class 3 is large (> $30 \mathrm{kDa})$ and heatresistant. Class 4 is the complex bacteriocins containing proteins and other chemical moieties (lipid or carbohydrate) (7).

In recent years, the bacteriocins have shown anti-bacterial, anti-fungal and anti-viral activities that promoted their application in pharmaceutical and therapeutic compounds. Their application in natural ingredients, preservatives and salutary products, in controlling bacterial infections and in the treatment of urinary tract infection (UTI) has attracted the attention of many scientists (811).

Since different Proteus strains are the common causes of UTI (12) and bacteriocin-producing Lactobacilli may have a role against these bacteria (13), this study aimed to investigate the antimicrobial effect of bacteriocin in the culture supernatant fluid of Lactobacilli (as probiotic strains) under various physicochemical conditions.

\section{MATERIAL AND METHODS}

Bacterial strains used and culture conditions The standard probiotic strains of $L$. acidophilus (ATCC 4356) and L. plantarum (ATCC 8014 ) as bacteriocin-producing strains, and the pathogenic strains of Proteus mirabilis (ATCC 7002) and P. mirabilis OXK (ATCC 15146) as common causes of UTI were obtained from the collection center of the industrial infectious fungi and bacteria at the Iranian Research Organization for Science and Technology and the Pasteur Institute of Iran.

In order to produce an active bacterial culture, the purchased lyophilized powders of Lactobacilli were transferred to the tubes containing $5 \mathrm{ml}$ de Man, Rogosa and Sharpe (MRS) broth and then incubated at $37{ }^{\circ} \mathrm{C}$ with $5 \% \mathrm{CO}_{2}$ for 24 to 48 hours. They were then cultured on MRS agar plates for storage.

After reduction in brain heart infusion broth, the Proteus strains used to determine the antimicrobial properties were cultured in nutrient broth at $37{ }^{\circ} \mathrm{C}$ under aerobic conditions.

\section{Preparing lactobacilli culture supernatant fluid}

The studied Lactobacillus strains were grown in MRS broth and then incubated at $37^{\circ} \mathrm{C}$ with $5 \% \mathrm{CO}_{2}$ in aerobic conditions for 24 hours. The $\mathrm{pH}$ of culture supernatant fluid of Lactobacillus strains were neutralized by sodium hydroxide $(\mathrm{NaOH})$. The culture supernatant fluid containing bacteriocin was 
centrifuged at $10000 \mathrm{~g}$ for 10 minutes. The obtained fluid was then sterilized by filtration using 0.2-micron filters (14).

Catalase test and evaluating acid production

The catalase test was performed for all Lactobacillus samples obtained from their 48hour liquid culture in the MRS.

One loop of fresh bacterial culture was transferred on the agar medium and one to two drops of hydrogen peroxide was added by a Pasteur pipette. The quick emergence and continuous production of gas bubbles indicate a positive reaction for the test (15).

In order to evaluate acid production, after incubation at $37{ }^{\circ} \mathrm{C}$ with $5 \% \mathrm{CO}_{2}$ in anaerobic conditions, the $\mathrm{pH}$ of the Lactobacillus strains culture supernatant fluid was measured using a pH meter (16).

Evaluation of bacteriocin production under various conditions

The effect of different enzymes on the antimicrobial activity of culture supernatant fluid of Lactobacilli

One $\mathrm{mg} / \mathrm{ml}$ of pepsin and trypsin and $5 \mathrm{mg} / \mathrm{ml}$ of catalase were separately added to the 24-hour culture supernatant fluid of bacteriocin-producing Lactobacillus strains. The $\mathrm{pH}$ of the fluid was neutralized with $\mathrm{NaOH} 1 \mathrm{~N}$. After one hour of incubation at 37 ${ }^{\circ} \mathrm{C}$, the antimicrobial properties of the culture supernatant fluid treated with different enzymes was investigated against Proteus strains using Microscale Optical Density Assay (MODA) (17).

\section{Relative extraction of Bacteriocin}

One loop of bacteriocin-producing Lactobacilli was cultured in $250 \mathrm{ml}$ Erlenmeyer flasks containing $50 \mathrm{ml}$ sterile MRS broth. The flasks were incubated at $37{ }^{\circ} \mathrm{C}$ in Candle jar. When the optical density of sample reached 0.5 McFarland $\left(1.5 \times 10^{8} \mathrm{CFU} / \mathrm{ml}\right), 5 \%$ of it was inoculated into the flasks containing $100 \mathrm{ml}$ MRS broth.

The antimicrobial agent was produced under suitable conditions with optimum temperature and $\mathrm{pH}$. The $\mathrm{pH}$ was measured and recorded after 24 hour of incubation and changed to 6.57 range by adding sufficient amount of $\mathrm{NaOH}$ $1 \mathrm{~N}$.

After neutralizing in sterile conditions, the microbial suspension of culture medium was centrifuged at $6000 \mathrm{~g}$ for 20 minutes at $4{ }^{\circ} \mathrm{C}$ to separate cell mass. Then, the sufficient amount of ammonium sulfate was weighed [50\% saturation for L. acidophilus (18) and 90\% saturation for L. plantarum (17)] and slowly added to the flasks that were placed on ice. The samples were placed at $4{ }^{\circ} \mathrm{C}$ for one night to dissolve ammonium sulfate completely.

The contents of the flask including the resulted sediment and the sediment-containing solution were transferred to sterile tubes and the tubes were centrifuged at $10000 \mathrm{~g}$ for 40 minutes at 4 ${ }^{\circ} \mathrm{C}$.

The supernatant was removed and the resulted sediment was resuspended in one $\mathrm{ml}$ of $0.05 \mathrm{M}$ sodium phosphate buffer ( $\mathrm{pH} 7)$. The result of dialysis (using dialysis bag with $12.000 \mathrm{KDa}$ cut off) was used as semi-purified bacteriocin.

Evaluating the antimicrobial activity of Lactobacilli culture supernatant fluid

MODA was used to evaluate the antimicrobial activity of Lactobacilli culture supernatant fluid. In this method, a 96 microplate was used and $100 \mu \mathrm{l}$ of Proteus strains tested (at a ratio of 1: 10000 in nutrient broth) was poured into each well. Next, $15 \mu \mathrm{l}$ of semi-purified bacteriocin from cultured Lactobacillus strains was poured into the wells.

The optical density of the samples was read at 600nm (using ELISA reader) after 24-hour incubation at $37{ }^{\circ} \mathrm{C}$. The difference between control wells (medium) and test wells (semipurified bacteriocin from cultured Lactobacilli) was reported as the antimicrobial activity against pathogenic strains. Each test was performed in triplicate to reduce error.

In separate wells, the MRS broth was used as culture control and the wells without semipurified bacteriocin were used as growth control (17).

Effect of different conditions on the antimicrobial activity of bacteriocinproducing lactic acid bacteria

Temperature: In order to evaluate the effect of temperature, the semi-purified bacteriocin was divided into 4 tubes. Tube 1,2 and 3 were placed at $100{ }^{\circ} \mathrm{C}$ for 10,30 and 60 minutes, respectively. Tube 4 was autoclaved at $121{ }^{\circ} \mathrm{C}$ for 15 minutes (17).

$\mathrm{pH}$ : For this purpose, $\mathrm{pH}$ of Lactobacillus culture medium (in the range of 4 to 10) was changed and after culture of various strains and 24-hour incubation in microaerophilic conditions with $5 \% \mathrm{CO}_{2}$, the antimicrobial activity of each sample was evaluated using MODA. Without changing the $\mathrm{pH}$, the MRS medium ( $\mathrm{pH}=5.7)$ was used as control (19). Addition of $\mathrm{NaCl}$ : the percentage of $\mathrm{NaCl}$ was changed in the culture medium (from $1 \%$ to $4 \%$ ), and then the antimicrobial activity was 
evaluated using MODA after 24 hours of growth in microaerophilic conditions with $5 \%$ $\mathrm{CO}_{2}(20)$.

\section{RESULTS}

Antimicrobial activity of semi-purified bacteriocin

Table 1 shows the results of the antimicrobial activity of semi-purified bacteriocin using MODA. The results of reading absorbance at $600 \mathrm{~nm}$ are after the addition of filtered $(0.22 \mu \mathrm{m}$ pore size $)$ Lactobacilli culture supernatant fluid.

The antimicrobial activity of the culture supernatant fluid of Lactobacillus strains are shown as percentage of difference in the growth of bacterial cells compared to the control. A good inhibitory activity was observed against all tested Proteus strains.

The culture supernatant fluid of semi-purified bacteriocin-containing Lactobacillus strains showed $77.78 \%$ and $97.78 \%$ inhibitory activity against all tested strains compared to the untreated control. The most significant inhibitory activity was observed against $P$. mirabilis OXK (ATCC 15146) with more than 97\% inhibitory activity, in comparison with the untreated control.

L. acidophilus and L. plantarum strains also reduced the $\mathrm{pH}$ of culture medium to about 4.5 and 4 , respectively. After treating the culture supernatant fluid of Lactobacilli with different enzymes as well as neutralization using $\mathrm{NaOH}$ $1 \mathrm{~N}$ and one hour incubation, the percentage of difference between the optical density of the wells containing culture medium (control) and the wells containing Lactobacilli culture supernatant fluid (test) reduced significantly in all test cases. This means that the enzymes and neutralization of its acid affect the antimicrobial activity. Pepsin showed the greatest effect in each case. The results are shown in figure 1 and 2.

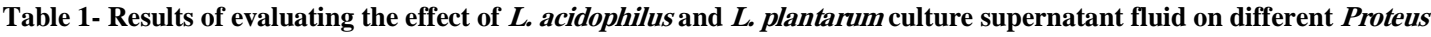
strains by the MODA method and comparing the percentage of difference in the growth of bacterial cells

\begin{tabular}{|c|c|c|c|}
\hline & \multirow[b]{3}{*}{ P. mirabilis OXK(ATCC 15146) } & & \multirow{3}{*}{$\begin{array}{l}\text { Lactobacilli culture } \\
\text { supernatant fluid }\end{array}$} \\
\hline & & Absorbance at $600 \mathrm{~nm}$ & \\
\hline & & P. mirabilis (ATCC 7002) & \\
\hline 0.683 & 0.507 & $\begin{array}{l}\text { Pathogenic bacteria (growth } \\
\text { control) }\end{array}$ & $\begin{array}{c}\text { L. acidophilus } \\
\text { (ATCC 4356) }\end{array}$ \\
\hline 0.540 & 0.463 & Culture medium (control) & \\
\hline 0.012 & 0.053 & $\begin{array}{l}\text { Culture supernatant fluid of } \\
\text { L. acidophilus (test) }\end{array}$ & \\
\hline $97.78 \%$ & $88.55 \%$ & $\begin{array}{l}\text { Difference in the growth of } \\
\text { bacterial cells }(\%)\end{array}$ & \\
\hline 0.683 & 0.507 & $\begin{array}{c}\text { Pathogenic bacteria (growth } \\
\text { control) }\end{array}$ & $\begin{array}{l}\text { L. plantarum } \\
\text { (ATCC 8014) }\end{array}$ \\
\hline 0.540 & 0.463 & Culture medium (control) & \\
\hline 0.120 & 0.033 & $\begin{array}{l}\text { Culture supernatant fluid of } \\
\text { L. plantarum (test) }\end{array}$ & \\
\hline $77.78 \%$ & $92.87 \%$ & $\begin{array}{l}\text { Difference in the growth of } \\
\text { bacterial cells }(\%)\end{array}$ & \\
\hline
\end{tabular}




\section{DISCUSSION}

Since Proteus treatment is of great importance in UTIs, the continual use of antibiotics can cause antibiotic resistance and treatment-resistant infections (21). In recent years, the use of probiotics such as various Lactobacillus strains has attracted a lot of attention for prevention and treatment of UTI as alternative treatments (22). Lactobacilli have strong antagonist activity against a large number of pathogenic bacteria by producing organic acids, hydrogen peroxide, diacetyl, inhibitory enzymes and bacteriocins (4). The role of lactic acid bacteria in the treatment of infections caused by Proteus has been observed (23). $L$. plantarum and $L$. acidophilus good inhibitory activities against UTI-causing strains are of great significance and importance. Other scientists $(17,18,24$, and 25) have considered such inhibitory activity against common pathogens that cause hospital infections and food spoilage. Lash et al. study (2005) on the bacteriocin extracted from L. plantarum (ATCC 8014) ,using MODA, showed more than $90 \%$ difference in the growth of bacterial cells against Grampositive and Gram-negative bacteria such as Escherichia coli, Pseudomonas aeruginosa, Serratia marcescens, Shigella flexneri, Salmonella Typhimurium, Staphylococcus aureus, Listeria innocua and S. epidermidis. In agreement with our results, this indicates the presence of antimicrobial activity due to Lactobacillus bacteriocin (17). This inhibitory effect could also be due to high sensitivity of the MODA, its applicability and evaluating the antagonistic property of culture supernatant fluid containing bacteriocin and pathogen stains in the liquid medium. Various studies have demonstrated that $L$. acidophilus and $L$. plantarum can reduce or inhibit the growth of $P$. mirabilis as a common cause of UTI, through production of bacteriocins (26). Mohankumar study (2011) showed that $L$. acidophilus had an inhibitory effect on the growth of Proteus and found that this inhibitory effect was mainly due to production of bacteriocins by L. acidophilus (14).

It is observed that the antimicrobial peptides or proteins produced by lactic acid bacteria often inhibit the growth of Gram-positive bacteria, while the low molecular weight compounds such as lactic acid have a higher inhibitory effect on the growth of Gram - negative pathogens (27).

However, since the antimicrobial effect of potential lactic acid production by Lactobacilli in this study was eliminated by neutralizing the $\mathrm{pH}$, the extracted antimicrobial compound performed well against Proteus (Gramnegative). De vuyst et al. also showed that the bacteriocin produced by $L$. acidophilus was more effective against Gram-negative bacteria in comparison with the gram-positive bacteria. Nevertheless, the antimicrobial compounds produced by Lactobacillus has shown different spectrum of effect on Gram-positive and Gram-negative bacteria in various studies (28). Since bacteriocins and the molecules similar to bacteriocins are directly made as polypeptides or pre-polypeptides (29). The sensitivity of bacteriocin existed in various enzymes (trypsin,pepsin and catalase) was measured, and the effect of $\mathrm{H}_{2} \mathrm{O}_{2}$ and produced acid was neutralized. The results showed a decreased inhibitory activity compared with untreated supernatant fluid (figure 1 and 2), emphasizes that the inhibitory compounds are bacteriocins with protein nature. Similar results were also observed in other studies $(6,17,18,29,30)$.

After confirmation of bacteriocin production, relative separation of these protein molecules was performed by ammonium sulfate deposition method and then dialysis of proteins. The effect of various physicochemical conditions on bacteriocin production and antimicrobial activity was measured. The results showed that the inhibitory activity is sensitive to heat, because its activity was eliminated at $100{ }^{\circ} \mathrm{C}$ for 10 minutes and 30 minutes in case of $L$. acidophilus and L. plantarum, respectively. Autoclaving at temperatures above $121{ }^{\circ} \mathrm{C}$ also eliminated the inhibitory property (figure 7 and 8). The inhibitory activity remained a little stable in the $\mathrm{pH}$ range, while the highest activity was observed in medium with $\mathrm{pH}$ 5-7 for both strains compared to the controls (figure 3 and 4).

In agreement with the results of other studies, the relative stability to heat and need for various culture medium conditions in terms of $\mathrm{pH}$ for production of the inhibitory compounds in the culture supernatant fluid of Lactobacilli confirms that these compounds are bacteriocins with protein nature (31-33). 


\section{CONCLUSION}

The results of this study showed that $L$. acidophilus and $L$. plantarum have suitable inhibitory activity against Gram-negative bacteria (Proteus). These inhibitory compounds are capable to remain relatively stable when facing temperature and proteolytic enzymes. These antimicrobial liquids are able to produce bacteriocins in both strains in $\mathrm{NaCl}$ range of 1 to $4 \%$ and $\mathrm{pH} 5$ to 7 and remain relatively resistant to temperature and $\mathrm{pH}$ conditions. These inhibitory compounds in the culture supernatant fluid of L. acidophilus and $L$. plantarum could be classified as bacteriocins, which have protein nature. Thus, they are considered suitable for use in food and pharmaceutical industries. Finally, it is suggested to conduct further molecular studies

\section{REFERENCES}

1. Lilly DM, Stillwell RH. Probiotics; Growth Promoting Factors Produced by Microorganisms. Science. 1965; 147(3659): 747-8.

2. Fuller R. Probiotics in man and animals. JAppl Bact 1989; 66(5): 365-78.

3. Ouwehand A, Vesterlund S. Health Aspects of Probiotics. IDrugs. 2003; 6(6):573-80.

4. Piard JC, Desmazeaud M. Inhibiting Factors Produced by Lactic Acid Bacteria:Oxygen Metabolites and Catabolism En-products. Lait. 1991;71:525-41.

5. Cleveland J, Montville TJ, Nes IF, Chikindas ML. Bacteriocins: Safe, Natural Antimicrobials for Food Preservation. Int JFood Microbiol. 2001;71(1):1-20.

6. Klaenhammer TR. Bacteriocins of Lactic Acid Bacterial. Biochimie. 1988; 70(3): 337-49.

7. Klaenhammer TR. Genetics of Bacteriocins Produced by Lactic Acid Bacteria. FEMS Microbiol Rev. 1993;12(1-3): 39-85.

8. Riley MA, Wertz JE. Bacteriocins Diversity: Ecological and Evolutionary Perspectives. Biochim. 2002; 4(5-6): 357-64.

9. Nemcova R. Criteria for selection of lactobacilli for probiotic use. Veterinary Medicine. 1997; 42(1): 19-27.

10. Hanlin MB, Kalchayanand N, Ray P, Ray B. Bacteriocins of Lactic acid Bacteria in Combination have Greater Antibacterial Activity. J Food Prot. 1993; 56(3): 252-5.

11. Schillinger U, Lücke FK. Antibacterial activity of Lactobacillus sake isolated from meat. Applied and Environmental Microbiology. 1989; 55(8): 1901-6.

12. Breitenbach JM, Hausinger RP. Proteus mirabilis urease. Partial purification and inhibition by boric acid and boronic acids. Biochemical Journal. 1988; 250(3): 917.

13. Axelsson L. Lactic acid bacteria: Classification and physiology. Lactic acid bacteria: microbiology and functional aspects. Marcel Dekker, Inc./CRC Press 2004:1-66. on the nature of these compounds and perform clinical trials.

\section{ACKNOWLEDGMENTS}

This article is derived from a thesis titled 'investigating the effect of secondary metabolites of some probiotic bacteria on urease activity and swarming motility by Proteus' in 2012-13 academic year at Alzahra University, Tehran. The help of all those who have assisted us in this study is greatly appreciated.

\section{CONFLICT OF INTEREST}

All contributing authors declare no conflicts of interest.

14. Mohankumar A, Murugalatha N. Characterization and antibacterial activity of bacteriocin producing Lactobacillus isolated from raw cattle milk sample. International Journal of Biology. 2011; 3(3): 128.

15. Saginur R, Clecner B, Portnoy J, Mendelson J. Superoxol (catalase) test for identification of Neisseria gonorrhoeae. Journal of clinical microbiology. 1982; 15(3): 475-7.

16. Tomas MS, Ocana VS, Wiese B, Macias ME. Growth and lactic acid production by vaginal Lactobacillus acidophilus CRL 1259, and inhibition of uropathogenic Escherichia coli. Journal of Medical Microbiology. 2003; 52(Pt 12): 1117-24.

17. Lash BW, Mysliwiec TH, Gourama H. Detection and partial characterization of a broad-range bacteriocin produced by Lactobacillus plantarum (ATCC 8014). Food Microbiology. 2005;22(2-3):199-204.

18. Han KS, Imm JY, Oh S, Jeon WM, Kim SH. Bacteriocin Produced by Lactobacillus acidophilus ATCC 4356. Food Science and Biotechnology. 2002; 11(5): 531-6.

19. Gardini F, Martuscelli M, Caruso M, Galgano F, Crudele M, Favati F. Effects of $\mathrm{pH}$, temperature and $\mathrm{NaCl}$ concentration on the growth kinetics, proteolytic activity and biogenic amine production of Enterococcus faecalis. International Journal of Food Microbiology. 2001; 64(1): 105-17.

20. Ruiz-Barba J, Cathcart D, Warner P, Jiménez-Díaz R. Use of Lactobacillus plantarum LPCO10, a bacteriocin producer, as a starter culture in Spanish-style green olive fermentations. Applied and environmental microbiology. 1994; 60(6): 2059-64.

21. Lim IS, Lee HS, Kim WY. The Effect of Lactic Acid Bacteria Isolates on the Urinary Tract Pathogens to Infants In Vitro. J Korean Med Sci. 2009; 24(1): 57-62.

22. Bruce AW, Reid G. Intravaginal Instillation of Lactobacilli for Prevention of Recurrent Urinary Tract Infections. Can J Microbiol. 1988; 34: 339-43. 
23. Coeuret V, Dubernet S, Bernardeau M. Isolation, Characterization and Identification of Lactobacilli Focusing Mainly on Cheeses and Other Dairy Products. Lait. 2003; 83: 269-306.

24. Franz CMAP, Du Toit M, Olasupo NA, Holzapfel WH. Plantaricin $D$, a bacteriocin produced by Lactobacillus plantarum BFE 905 from ready-to-eat salad. J Appl Microbiol. 1998; 26(3): 231-5. DOI: 10.1046/j.1472-765X.1998.00332.x

25. Enan G, el Essawy AA, Uyttendaele M, Debevere J. Antibacterial activity of Lactobacillus plantarum UG1 isolated from dry sausage: characterization, production and bactericidal action of plantaricin UG1. Int J Food Microbiol. 1996; 30(3): 189-215.

26. Gibson GR, Roberfroid MB. Dietary modulation of the human colonie microbiota: introducing the concept of prebiotics. Journal of nutrition. 1995; 125(6): 1401-12.

27. Strus M, Pakosz K, Gościniak H, Przondo-Mordarska A, Rozynek E, Pituch H, et al. Antagonistic activity of Lactobacillus bacteria strains against anaerobic gastrointestinal tract pathogens (Helicobacter pylori, Campylobacter coli, Campylobacter jejuni, Clostridium difficile). Medycyna doswiadczalna i mikrobiologia. 2000; 53(2):133-42.
28. De Vuyst L, Vandamme EJ. Antimicrobial potential of lactic acid bacteria. Bacteriocins of lactic acid bacteria. Springer; 1994; 91-142.

29. Hammes WP, Vogel RF. The lactic acid bacteria, The genera of lactic acid bacteria. Glasgow BAaP, editor. Chapman and Hall: 2; 1995.

30. Tagg JR, Dajani AS, Wannamaker LW. Bacterion of Gram Positive Bacteria Bacteriology Reviews. 1976; 40(3): 722-50.

31. Van Reenen CA, Dicks LMT, Chikindas ML. Isolation,purification, and partial characterization of plantaricin 423, a bacteriocin produced by Lactobacillus plantarum. J Appl Microbiol. 1998;84:1131-7.

32. Messi P, Bondi M, Sabia C, Battini R, Manicardi G. Detection and preliminary characterization of a bacteriocin (plantaricin 35d) produced by a Lactobacillus plantarum strain. Int J Food Microbiol. 2001; 64(1-2): 193-8.

33. Muriana PM, Klaenhammer TR. Purification and Partial Characterization of Lactacin $F$, a Bacteriocin Produced by Lactobacillus acidophilus 11088. Applied and Environmental Microbiology. 1991;57(1):114-21. 